DOI: http://doi.org/10.22364/ruslat.glp.09

\title{
Татьяна Тернова
}

\section{Творчество М.Ю. Лермонтова как объект рецепции в пьесе А. Мариенгофа «Рождение поэта»"}

\begin{abstract}
В пьесе А. Мариенгофа «Рождение поэта» осмысливается формирование творческой мичности М.Ю. Аермонтова. Интертекстуальность становится наиболее показательным приемом, обскуживающим замысел Мариенгофа. Объектами апелмяции в пьесе являются стихотворения Аермонтова, в первую очередь, «Смерть Поэта», а также стихотворения А.С. Пушкина, К.Ф. Рылеева, А.И. ОАоевского и К.Н. Батюшкова. В тексте А. Мариенгофа интертекстуальность становится мишь приемом, а не способом выражения мировоззренческих установок. Он носит сугубо прикладной характер, будучи мотивированным не текстом и его внутренней жизнью, но отношением автора с затекстовой реальностью идеологически нагруженных 1950-х гг.
\end{abstract}

Ключевые слова: А. Мариенгоф, имажинизм, М.Ю. Аермонтов, Араматургия, интертекстуальность

Пьеса «РожАение поэта» написана А. Мариенгофом в 1950 году, в эпоху, хронологически Аалеко отстоящую от имажинистского творчества автора. Художественное мировоззрение А. Мариенгофа существенно трансформировалось в период изАания журнала «Гостиница Аля путешествующих

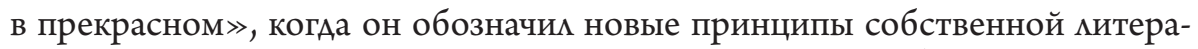
турной работы, сАелав ставку на значимость содержания («выйти из узких формальных рамок и развиться Ао миросозерцания»)2.

ПроизошеАшие в периоА «Гостиницы» трансформации были закреплены в Араматургии А. Мариенгофа 1930-х гг. («Мама», «Кукушка») и времени Великой Отечественной войны («Аенинградские Аевушки», «Егоровна $»$ и Ар.).

Тем не менее, школа имажинизма не могла пройти Аля автора бесслеАно. В реалистической пьесе «РожАение поэта» используются приемы, напрямую восходящие к митературе авангарда. Наиболее показательный из

1 Исследование выполнено при финансовой подАержке РФФИ в рамках научного проекта № 18-012-00476 А «Эстетическая новизна и литературность как проблемы теории и творческой практики XX века: авангардизм 1920-1930-х гг. и постмоАернизм 1970-1980-х гг.»

2 См. об этом Марков 2005: 212. 
них - сознательное конструирование интертекстуацьного пласта, который служит Аля выражения авторской позиции и созАания образа героя.

Текстостроительная интенция как вариант выражения авторского художественного сознания в пьесе мотивирована, таким образом, совершенно иначе, нежели это характерно Аля митературы авангарда. Будучи эмементом эстетической практики авангарАа, она проистекает из его базовых мировоззренческих установок, прежде всего, из представления о мире как тексте, «уничтожаются границы межАу письмом и всем, что кежит за его пределами (мир, жизнь, речь, история, сознание и т.А.» [Аексикон нон-классики 2003: 237]), элементы которого мишены иерархических связей. В поле тотально исчерпанных художественных возможностей, гАе «все уже сказано», еАинственным ресурсом новизны оказывается то, что вынесено на периферию ценностного сознания - маргинальное. В результате такой специфической «валоризации» возникает особый тип текста, созидаемого в результате разрушения культурных параАигм, Аискурса классической и модернистской митературы. Элементы текстов-предшественников оказываются конструктами новой текстовой единицы, в которой не имеют центрального, смысмового, определяющего в эстетическом и смысловом отношении значения.

В тексте А. Мариенгофа интертекстуальность становится мишь приемом, а не способом выражения мировоззренческих установок. Он носит сугубо прикладной характер, будучи мотивированным не текстом и его внутренней жизнью, но отношением автора с затекстовой реальностью илеологически нагруженных 1950-х гг. А. Мариенгоф создает многослойное высказывание о революции и ее корнях, о Аермонтове как поэте-бунтаре, своеобразном провозвестнике будущих политических преобразований.

Аля А. Мариенгофа в пьесе «РожАение поэта» Аермонтов - автор исключительно политической, социальной проблематики. Его рожАение как Творческой Аичности оАнозначно возвоАИтся К созАанию стихотворения «Смерть Поэта». В тексте провозглашается несколько миний преемственности, причем творческий и идеологический сюжет сливаются воеАино: Аермонтов оказывается прямым продолжателем миссии Пушкина, также воспринимаемого как поэт гражАанской темы, бунтарство последующих эпох возводится к Аекабризму. Пушкин и Аермонтов оказываются связаны посредством фигуры А.И. ОАоевского, ответившего А.С. Пушкину на его стихотворение «Во глубине сибирских руа...» своим посланием «Струн вещих пламенные звуки ... » и знакомого Аермонтову по Кавказу.

Интертекстуальное поле пьесы исключительно обширно и включает прямые цитаты из творчества

М.Ю. Аермонтова - 10 («К $\mathrm{K}^{* * *} »$, «Москва, Москва!... Аюбцю тебя как сын... », «Гусар», «Смерть поэта», «Мой демон», «Великий муж! ЗАесь нет награды...», «ПреАсказание», «Узник», «Не смейся наА моей пророческой тоской ... », «Кинжам»),

А.С. Пушкина - 3 («Моя родословная», «Во глубине сибирских руа...», «К Чаадаеву $)$, 
К.Ф. Рылеева - 2 («Вере Николаевне Столыпиной», с А.А. Бестужевым - из цикла «Агитационные песни»),

А.И. ОАоевского - 1 («Струн вещих пламенные звуки ...»),

К.Н. Батюшкова - 1 («Разиука»).

Приводятся как отдельные фразы, так и значительные, вплоть Ао полстраницы авторского текста, фрагменты произведений, а иногАа и тексты целиком. Учитывая общий объем пьесы, 63 страницы в собрании сочинений А. Мариенгофа (с. 357-420) и 89 (с. 3-92) в изАании 1959 гоАа, можно выявить частотность цитирования: на одну страницу текста приходится в среднем 5-8 строк цитирования. Такой объем цитирования, вне всяких сомнений, преАставляет собой если не уникальный, то Аостаточно реАкий скучай в произведении, где интертекстуальность становится не более чем приемом и автор не претендует на создание текста-центона и игру с читателем.

В этой связи вспомним о том, что интертекстуальность была чрезвычайно характерна Аля Аитературной работы имажинистов, что неоднократно подчеркивалось исследователями (см. [Богумим 2004; Иванова 2002; Арозаков 2014; Мекш 2003] и Ар).

Интертекстуальность имажинистского текста имела программный характер и вытекала из принципиального Аля имажинистов неразмичения высокого и низкого, центрального и периферийного, массового и элитарного: «Подобные скрещивания чистого с нечистым скужат способом заострения тех заноз, которыми в должной мере щетинятся произведения современной имажинистской поэзии», - писал А. Мариенгоф в теоретическом трактате 1920 года «Буян-остров» (Мариенгоф 1920: 13). Специфика отношения к чужому слову как авторская стратегия была обозначена В. Шершеневичем еще на этапе выхода за рамки футуристической концепции, в работе «Футуризм без маски»: «Мы все ученики предшествовавших поэтов и не муАрено, что их рука оставмяет свой слеА. ПоАражание характеризуется тем, что этот смеА остается не переработанным. ОАно Аело, если мы смотрим с уважением и вникновением на работу учителей, Аругое - если рука его тени исправмяет кажАый штрих» (Шершеневич 1913: 9). Такой поАхоА опреАеляет варианты имажинистской интертекстуальности. Аоминирующими способами цитирования оказываются аммюзия и квазицитата (цитата с трансформацией смысла исходного текста). Степень искажения первоисточника позволяет делать определенные (с поправкой на игровые установки имажинизма) выводы об отношении к тем или иным китературным преАшественникам.

Интертекстуальный посыл в митературной работе имажинистов во многом мотивирован особенностями имажинистской художественной антропологии. Игровой образ поэта-трикстера, суммирующий «маски» мирического героя имажинистов, предполагает отношение к чужому слову как объекту игры. Об этом пишет Т.А. Богумия, цитируя стихотворение из раннего сборника В. Шершеневича «Автомобилья поступь»: «Маска 
имеет прямое отношение к “чужесловию”, имитации речевой и стилевой мичины, что воплощается в сквозном Аля творчества Шершеневича мотиве переодевания (“костюм романтика мне сегодня узок” в “Отчего сегодня так странна музыка?”) (Богумим 2004: 62).

Имажинисты неоднократно обращались к образу Аермонтова. Так, одним из показательных Аля митературной работы Шершеневича был образ «черного ангела катастроф» (вспомним одноименную поэму автора), «восходящий к романтическим поэмам М.Ю. Аермонтова "Ангел смерти" (1831), “Азраил” (1831) и “Аемон” (1829-1939)» (Шершеневич 1997: 483). Аополнительным контекстом Аля поэмы того же В. Шершеневича «Песня песней» была поэма М. Аермонтова «Аемон»: «В твоем имени Аемон Бензина и Тамара Трамвайных Звонков». В стихотворении «БроАяга страстей» («Итак итог» (1926) Шершеневич использовац отсылку к стихотворению Аермонтова «На севере Аиком...» («Петь на севере о памьме южной»).

К творчеству Аермонтова обращался и А. Мариенгоф. Этому вопросу посвящены исследования В.А. Сухова (Сухов 2015; Сухов 2016а; Сухов 20166), А.А. Николаевой (Николаева 2016). В.А. Сухов в своих статьях УАемял внимание пьесе «РожАение поэта». Им быц обнаружен значимый факт посещения Есениным и Мариенгофом «Аомика Аермонтова» в Пятигорске в 1920-м году. О. Аемидов, составитемь собрания сочинений А. Мариенгофа, приводит письма А. Мариенгофа жене, А. Никритиной, свидетельствующие о том, что Мариенгоф неоднократно бывац в санатории Пятигорска в начале 1950-х гг. (Мариенгоф 2013: I, 702-726). В свою очередь, В.А. Сухов отмечает наличие в фондах мермонтовского музея экземпляра «РожАения поэта» с Аарственной надписью «Музею “Аомик

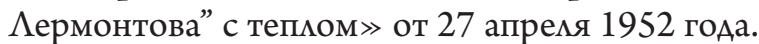

А. Мариенгоф посвятил пьесу своему близкому Аругу, известному мермонтоведу Б.М. Эйхенбауму. «Мне мой Аермонтов Аорог...» - писал А. Мариенгоф жене (Мариенгоф 2013: I, 696). Рискнем предположить, что Аорог автору текст быц не только содержательной стороной, но и своей сАеланностью, проработанностью составцяющих его мотивов и образов.

Как мы уже отмечали, Аермонтов в тексте Мариенгофа, прежде всего, преАстает как поэт-бунтарь. В то же время это и философ, и пророк, и мальчишка с присущей ему горячностью, за которого волнуется мюбящая бабушка, это гений на этапе своего становмения. Примечательно, что мариенгофовский Аермонтов не одинок. У него есть соратники, причем в близком окружении: кузина Машенька, родственник Раевский. Есть у него и оппоненты, АюАи толпы - офицерской (Бухаров, Бугаков), светской (Столыпин).

Штрихами обозначен портрет Аермонтова - небольшого роста молоАой человек, но с разбойничьими глазами: «Княгиня Сольскал. Ростом невемик, тоненькие усики и черные глазища. Графиня Нессельроде. Как у разбойника» (Мариенгоф 2013: 382). 
ГАаза - один из показательных портретных эмементов в тексте. См.: «Все молчат. Смотрят Аруг на Аруга широко раскрытыми глазами» (Мариенгоф 2013: 384); «Входит Николай. Гцаза навыкате, говорит громко. У него много масок и нет мица» (Мариенгоф 2013: 385); «Николай <...> бесцеремонно останавливает на ней свои оловянные глаза» (Мариенгоф 2013: 387), «Аермонтов. Потому что у вас Ауша - в глазах» (Мариенгоф 2013: 393), «Аермонтов. У Николая они оловянные» (Мариенгоф 2013: 415).

Показателен также голос. Аермонтов говорит по-разному («Потеряв самообладание»; «Опять взрываясь»; «Тихо»), его оппоненты - однопланово «Булгаков (поет) Аля нас в беседе голосистой... » (Мариенгоф 2013: 396).

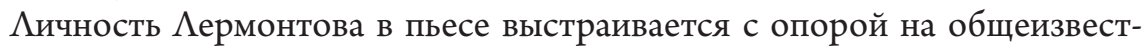
ные биографические сведения и смешивается с образом мирического героя его произведений и героя прозы: сам поэт преАстает своеобразным героем времени. ОАна из показательных его черт - склонность к рефмексии, которая как раз и позволяет раскрыть его переА зрителями. Он сам характеризует себя, осознавая свою противоречивость: «Аермонтов. Аа, праваа ваша, - Ава человека словно во мне сиАят ОАин из них живет жизнью паркетной. В гостиных! А Аругой - он судит его, этого танцора бального. Он говорит ему: “Э, брат, а веАь жизнь твоя пустая и глупая шутка” 》 (Мариенгоф 2013: 360). Герой Ауши Аермонтова - Аемон. ОАнако тема Аемонизма в «РожАении поэта» не развита всесторонне и не доведена Ао мистицизма. В Аухе эпохи созАания в пьесе вводятся богоборческие мотивы: «Уж если он Аопустил, чтобы Пушкина... ваш бог» (Мариенгоф 2013: 414), «Бог, бог, бог... Нет, ОАоевский, - демон! Он как-то ближе сердцу моему, этот непокорный дух - Аух возмущения, свободы и познания. Я еще когАа-нибудь напишу о нем поэму» (Мариенгоф 2013: 417); «И наА вершинами Кавказа / Изгнанник рая прометал!..» (Мариенгоф 2013: 417).

Неоднозначноть внутреннего содержания героя объективно присуща ему, отсюда и реакция на него со стороны: «Бухаров. Аа кто ты - гусар ими бумагомаратель? Аермонтов. (тихо) Бумагомаратель» (Мариенгоф 2013: 399).

Противоречивость героя становится свидетельством его внутреннего перепутья, роста: «За нынешний день я Аалеко ушел по Аороге жизни» (Мариенгоф 2013: 361). На наших глазах в нем начинает доминировать оАна из сторон кичности, которая и делает его поэтом, составившим славу России.

$\Lambda$ ермонтов в изображении Мариенгофа прямолинеен в оценках: «Аермонтов. А еще - пистолет негодяя» (Мариенгоф 2013: 359); о Столыпине: «САыхал? Видал? Видал этого раба с морнетом? Этого картавящего палача Пушкина?» (Мариенгоф 2013: 380), ироничен, саркастичен (называет Николая «венценосцем»), высоко образован, практически мыслит цитатами: «Аермонтов. Жить и умереть танцуя» (Мариенгоф 2013: 360). 
Из этого симбиоза мичности, культуры и эпохи начинает формироваться корпус основных произведений поэта: «А веАь я, Станислав, всю французскую изящную словесность, вкупе с их $А$ амартином, не раздумывая отАам за наши народные сказы. Куда в них больше поэзии! ... Я уже начал писать в народном духе. Понимаешь - песнь! Про царя Ивана Васильевича, молоАого опричника и уАалого купца Камашникова» (Мариенгоф 2013: 378); «О, я еще не дописал свою “Смерть Поэта” » (Мариенгоф 2013: 380).

Образ Аермонтова ассоциирован с деталью, упоминание которой приобретает мейтмотивный характер, - кинжалом, саблей. (см. первую ремарку: «Комната Аермонтова. Ковер с восточным узором. ... На нем оружие: сабля, кинжал, пистолеты» (Мариенгоф 2013: 358) и далее: «Хватает саблю; Вырывает из ножен»). Так возникает один из контекстов пьесы стихотворение ермонтова «Поэт». Образ кинжала в тексте развивается. Это и предмет мюбования, юношеская забава, и предвестье беды, и символ бунта ${ }^{3}$.

Тема бунта, революционности - одна из основных в пьесе. Оружием поэта преАсказуемо становится слово. Корни поэтического бунтарства $\Lambda$ ермонтова находятся в эпохе декабризма, тем более что $А$ ермонтов оказывается близко знаком с А.И. ОАоевским.

Аиалог Аермонтова с ОАоевским - еАва ки не центральный эпизоА пьесы. Именно ОАоевскому вменена констатация связи пушкинского и мермонтовского творчества: «Одоевский. Пушкинский Апоммон требует нас к священной жертве» (Мариенгоф 2013: 418). Именно в Аиалоге с ОАоевским проведена связь и настоящего (эпохи Пушкина и $\Lambda$ ермонтова) с буАущим, временем революции: «Аермонтов. Я слыхал, ОАоевский, что Вы написали "Ответ" на пушкинское "Послание"? (Мариенгоф 2013: 419); «Иермонтов. "Из искры возгорится пламя”!.. Аа веАь это пророчество» (Мариенгоф 2013: 419).

Тема пророчества общественного и мичного характера неоднократно заявлена в пьесе Мариенгофа. Так, как пророчество подаются слова из пушкинского текста: «Россия вспрянет ото сна» (Мариенгоф 2013: 420), как пророчество звучат слова ОАоевского о славе $\Lambda$ ермонтова и поэтической

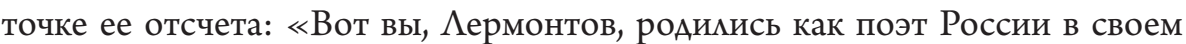
стихотворении на смерть Пушкина» (Мариенгоф 2013: 419), а также слова $\Lambda$ ермонтова о собственной судьбе: «Нет, Саша, мой век короткий».

Бунтарство становится подтекстом изображаемой Мариенгофом эпохи, революционность которой осознается и протореволюционерами, и ретрограАами: «Столыпин. Это, господа, Аекабристские речи!» (Мариенго $\phi$ 2013: 379), «Княгиня Сольская. О, эти стихи под стать песенке Рылеева» (Мариенгоф 2013: 384).

3 «Показывает кинжам» (Мариенгоф 2013: 391): «Елизавета Алексеевна. И до чего же я не Аюблю эти твои пистолеты и ножики!» (Мариенгоф 2013: 391); «(кричит) Кинжал!» (Мариенгоф 2013: 368). 
Бунтарство в изображении Мариенгофа становится не только словом, но и Аелом: стихи Аермонтова начинают распространяться: «Николай. Я получим их по городской почте, при письме и с наАписью весьма справеАмивой: “Воззвание к революции” (Мариенгоф 2013: 386); «Булгаков. И стали, черт побери, орать мне какую-то революционную белиберду о палачах гения, о черной крови ... (Мариенгоф 2013: 397). В качестве главного бунтарского «дема» - текста $\Lambda$ ермонтова - осмысляется «Смерть Поэта»: «Клейнмихель. Вы, господин корнет, свои стихотворением на смерть Пушкина приуготовмяли способы к бунту» (Мариенгоф 2013: 402); «Это мы жертвы бессердечного пера вашего! Карбонарского! Революционерского!» (Мариенгоф 2013: 403).

Собственно говоря, сюжет пьесы Мариенгофа разворачивается вокруг «Смерти Поэта» как факта и текста, в котором рожАается Аругой поэт, известный всей России. Невозможно остановить его вхожАение в сознание кажАого. Ему способствуют и Арузья, и враги: «Графиня Нессельроде. Кто же его и знал Ао этих возмутительных стихов?» (Мариенгоф 2013: 382); «Княгиня Сольская. ... уже весь Петербург читает» (Мариенгоф 2013: 384); «Кяейнмихель. На всю Россию проорал с невиданной наглостью» (Мариенгоф 2013: 407).

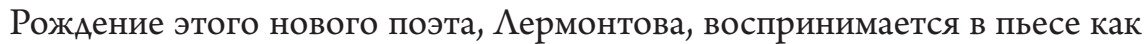
потребность России, отклик на ее запросы. ОтсюАа и активность апемляции к теме русскости, вообще значимой Аля зрелого творчества Мариенгофа (Тернова 2011), на ее страницах: «Желчь размилась ... Сегодня у кажАого русского человека - если он не Авуногая скотина - Аолжна желчь размиться» (Мариенгоф 2013: 360). Русскость в тексте становится оценочным понятием, а высшей инстанцией в оценке деяний современников становится русский нароА: «Русский язык!... Аа как это вы смеете судить о нем?» (Мариенгоф 2013: 379); Аермонтов - Столыпину: «Кто ты такой? Кто? Русский?» (Мариенгоф 2013: 376); «Раевский. Русский нароА никогАа им этого не простит» (Мариенгоф 2013: 377); «Жуковский. Аучшие из Аюдей эпохи испытывают «нестерпимую боль от несчастья, постигшего Россию» (Мариенгоф 2013: 411) (речь иАет о смерти Пушкина). Сами обстоятельства его кончины в результате Ауэли с иноземцем Аантесом позвомяют Мариенгофу актуализировать значимую Аля его зрелого творчества антитезу «свое» - «чужое» (Тернова 2012). ИАейные оппоненты монтова в пьесе принципиально чужАы русской культуре, о чем напрямую заявмяют: «Столыпин. Он иностранец, знатный иностранец, и наплевать ему на вашу "русскую славу"» (Мариенгоф 2013: 379); «Кяейнмихель. $<\ldots>$ у меня никогаа не бымо аппетита к отечественной поэзии» (Мариенгоф 2013: 381). Впрочем, на страницах пьесы высмеивается и имитация патриотизма: «Николай. Велика моя ответственность за него переА отечеством, переА Россией» (Мариенгоф 2013: 412).

В целом, пьеса о творческом становмения М. Аермонтова демонстрирует взгляды А. Мариенгофа зрелого периода творчества. Они уже 
абсолютно Аалеки от эстетических установок модернизма и авангарда. В качестве истока творческой биографии поэта автором осмысляется реальность. Творчество позиционируется как воплощение иичности, главных мыслей и чувств субъекта.

Стоит отметить, что сама поставленная в тексте Мариенгофа творческая задача - осмысление природы творчества - не нова и разрабатывамась в имажинистский периоА в «Романе без вранья», в центре внимания в котором находилась творческая судьба Есенина. Пьеса свидетельствует о том, что в разработке темы произошли существенные изменения: в периоА «Романа...» Мариенгоф, напротив, видел причины кичностных трансформаций Есенина в его творческих взметах и кризисах, следуя провозглашенному в «Буян-острове» тезису «искусство останавливает жизнь» (Мариенгоф 1920: 5).

Пьеса «РожАение поэта» представмяет собой постимажинистский реалистический вариант жизнетворческой концепции А. Мариенгофа, центральной фигурой которой становится творческая мичность.

\section{Литература}

Богумия, Т.А. (2004). В.Г. Шершеневич: феномен авторской субъективности: Аисс. ... канд. фимол. наук. Барнаум. 189 с.

Ароздков, В.А. (2014). Dum spiro spero. О Вадиме Шериеневиче, и не только. Статьи, разыскания, публикации. Москва: Водолей. 800 с.

Иванова, Е.А. (2002). Шершеневич и Маяковский: грани Аиалога. В: Проблемы митературного диалога. Саратов: ИзА-во Аатанова В.П. С. 122-127.

Иексикон нонклассики. Художественно-эстетическал культура ХХ века (2003). Бычков, В.В. / реА. Москва: Российская политическая энциклопедия (РОССПЭН). 607 с. Мариенгоф, А. (1920). Буян-остров. Москва: Имажинисты. 32 с.

Мариенгоф, А.Б. (2013). Собрание сочинений в 3 т. / сост Аемидов, О.В. Москва: Книжный Клуб Книговек.

Марков, В.Ф. (2005). Гостиница Амя путешествующих в прекрасном. Звезда. № 2. C. $211-218$.

Мекш, Э.Б. (2003). Поэт и время в книге стихов Вадима Шершеневича « Аошадь как мошаАь». В: Русский имажинизм: История. Теория. Практика. АрозАков, В.А., Захаров, А.Н., Савченко, Т.К. / реА. Москва: АИНОР. С. 277-290.

Николаева, А.А. (2016). Кермонтовская традиция и полемика с ней в пьесе В.Г. Шершеневича «ОАна сплошная нелепость» В: Словесное искусство Серебряного века и Русского зарубежья в контексте эпохи («Смирновские чтения»): сборник статей по итогам II МежАународной научной конференции (г. Москва, МГОУ, 22-23 января 2016 г.). Алексеева, М.Ф., Климчукова, В.Н., Крымова, С.В. / реА. М.: ИИУ МГОУ. С. 88-93.

Сухов, В.А. (2015). «Мне мой Аермонтов Аорог...» (А.Б. Мариенгоф о М.Ю. Аермонтове). В: Педагогический институт им. В.Г. Белинского : традииии u инновачии. Сборник статей научной конференции, посвященной 75-метию Пензенского педагогического института им. В.Г. Белинского Пензенского государственного университета. Пенза: Пензенский гос. университетт. С. 236-238. 
Сухов, В.А. (2016а). Евангельские мотивы в романе М.Ю. Аермонтова «Вадим» и в трагедии С.А. Есенина «Пугачев». В: Традиции и новации: культура, общество, мичность. Материалы третьих региональных образовательных РожАественских чтений. Пенза. С. 281-286.

Сухов, В.А. (20166). Аермонтовские традиции в творческой интерпретации С.А. Есенина. В: Сергей Есенин: Аичность. Творчество. Эпоха. Сб. науч. трудов / ИМАИ РАН; РГУ им. С.А. Есенина; Гос. музей-заповедник С.А. Есенина. МоскваКонстантиново-Рязань. С. 249-263.

Тернова, Т.А. (2000). История и практика русского имажинизма: Аисс. ... канА. фикол. наук. Воронеж. 225 c.

Тернова, Т.А. (2011). От имажинизма к советской митературе: тема русскости в произведениях А. Мариенгофа периода Великой Отечественной войны. В: Вестник Татарского государственного гуманитарно-педагогического университета. № 2 (24). C. 229-233.

Тернова, Т.А. (2012). Антитеза «свой-чужой» в комедии А. Мариенгофа «Шут Балакирев». В.: Образ европейца в русской и американской митературах: материалы IX межАународной научной конференции «Художественный текст и культура» / редкол. С.А. Мартьянова (отв. реА.) и ар. Владимир: Транзит-Икс. С. 101-106.

Шершеневич, В. (1913). Футуризм без маски: Компияятивная интродукция. Москва: Искусство. [На обл. - 1914]. 105 с.

Шершеневич, В.Г. (1997). Аисты имажиниста. Ярославль: Верхне-Волжское кн. изА.-во. 526 с.

\section{L̦ermontova daiḷrade kā recepcijas objekts A. Marienhofa lugā “Dzejnieka piedzimšana"}

Anatolija Marienhofa lugā "Dzejnieka piedzimšana” aplūkota Mihaila Ļermontova radošās personības veidošanās. A. Marienhofa iecere un mākslinieciskie pañēmieni ir saistīti ar intertekstualitāti. Apelācijas objekti lugā ir M. L,ermontova dzejoḷi “Dzejnieka nāve”, kā arī Aleksandra Puškina, Kondratija Riļejeva, Vladimira Odojevska un Konstantīna Batjuškova dzeja. Intertekstualitāte A. Marienhofa tekstā neatspogulo pasaules uzskatu, tas ir māksliniecisks paṇēmiens, kas saistīts ar ārpusteksta realitāti ideologiski noslogotajiem 20. gadsimta 50. gadiem.

\section{Lermontov's creativity as an object of reception in A. Mariengof's play "The Birth of a Poet"}

A. Mariengof's play “The Birth of a Poet” introduces the evolvement of the creative personality of $\mathrm{M}$. Lermontov and intertextuality becomes the most revealing device serving Marienhof's plan. The objects of appeal in the play are Lermontov's poems, first of all, "The Death of the Poet", as well as the literary works by A.S. Pushkin, K.F. Ryleev, A.I. Odoevsky, K. Batiushkov. In the text of A. Mariengof intertextuality becomes only a device, and not a means of expressing worldviews. It is of a purely applied character, being motivated not by the text and its inner life, but the author's relationship with the implicit reality of ideologically loaded 1950s. 